\title{
KEMAMPUAN PEMECAHAN MASALAH MATEMATIS DAN SELF-CONFIDENCE SISWA SMK MELALUI PEMBELAJARAN SINEKTIK DAN PEMBELAJARAN BERBASIS MASALAH
}

\section{(MATHEMATICAL PROBLEM SOLVING ABILITY AND SELF- CONFIDENCE OF SMK STUDENTS THROUGH SINEKTIK LEARNING AND PROBLEM BASED LEARNING)}

\author{
Veni Saputri ${ }^{1}$ \\ ${ }^{1}$ STKIP Media Nusantara Citra, veni.saputri@stkipmnc.ac.id
}

\begin{abstract}
Abstrak
Tujuan penelitian ini adalah untuk membandingkan pencapaian dan peningkatan kemampuan pemecahan masalah matematis dan pencapaian self-confidence matematika antara siswa yang belajar melalui model pembelajaran sinektik dengan model pembelajaran berbasis masalah. Penelitian ini meru22pakan penelitian kuasi eksperimen dengan pretestpostest design. Teknik pengambilan sampel yang digunakan adalah purposive sampling, sehingga diperoleh dua kelas eksperimen. Kelas eksperimen 1 dengan menggunakan model pembelajaran sinektik, sedangkan kelas eksperimen 2 dengan menggunakan model pembelajaran berbasis masalah. Instrumen yang digunakan adalah tes kemampuan pemecahan masalah matematis dan angket self-confidence matematika. Teknik analisis data dilakukan dengan menggunakan uji statistik perbedaan rerata dua sampel yang independen. Hasil penelitian menunjukkan bahwa: (1) tidak terdapat perbedaan pencapaian dan peningkatan kemampuan pemecahan masalah matematis yang signifikan antara siswa yang memperoleh model pembelajaran sinektik dengan model pembelajaran berbasis masalah dan (2) tidak terdapat perbedaan pencapaian selfconfidence matematika yang signifikan antara siswa yang memperoleh model pembelajaran sinektik dengan model pembelajaran berbasis masalah.
\end{abstract}

Kata kunci: Pembelajaran Berbasis Masalah, Pemecahan Masalah, SelfConfidence, Sinektik.

\begin{abstract}
This research aims to compare the achievement and enhancement in the mathematical problem solving ability and the achievement of mathematical self-confidence among students who learn through sinektik learning model with students learning through problem-based learning model. This research is a quasi-experimental research with pretest-posttest design. Sampling was done by purposive sampling technique, in order to obtain two classes. Experiment class 1 get learning with sinektik learning model, while the experimental class 2 get learning by using problem-based learning model. The instrument used are test of mathematical problems solving ability and mathematical self-confidence questionnaire. Data analysis was done using statistical test mean difference of two independent samples. Based on the research results, it is concluded: (1) there are not a significant differences in the achievement and enhancement in
\end{abstract}


mathematical problems solving ability of students who obtained sinektik learning model, compare to students who received problem-based learning model and (2) there is not a significant differences in the achievement in mathematical self-confidence of students who obtained sinektik learning model, compare to students who received problem-based learning model.

Keywords: Problem-Based Learning Model, Problem Solving, SelfConfidence, Sinektik

\section{PENDAHULUAN}

Salah satu tujuan mata pelajaran matematika di sekolah agar siswa mampu memiliki sikap menghargai kegunaan matematika dalam kehidupan, yaitu memiliki rasa ingin tahu, perhatian, dan minat dalam mempelajari matematika, serta sikap ulet dan percaya diri dalam pemecahan masalah. Pernyataan sebelumnya mengungkapkan bahwa pemecahan masalah dan rasa percaya diri sangat diperlukan dalam mencapai tujuan pembelajaran matematika. Dalam hal ini, pemecahan masalah matematis mempunyai dua makna yaitu sebagai pendekatan pembelajaran dan sebagai kemampuan matematis. Pemecahan masalah sebagai suatu pendekatan pembelajaran berarti untuk menemukan kembali dan memahami materi/konsep/prinsip matematika. Sedangkan pemecahan masalah sebagai kemampuan matematis berarti kemampuan untuk mengidentifikasi kecukupan data untuk pemecahan masalah, membuat model matematik, memilih dan menerapkan strategi, menginterpretasi hasil sesuai permasalahan asal dan memeriksa kebenaran hasil atau jawaban (Sumarmo, 2013).

Branca (Sumarmo, 2013) menyatakan bahwa pemecahan masalah matematis merupakan salah satu tujuan penting dalam pembelajaran matematika bahkan proses pemecahan masalah matematis merupakan jantung matematika. Setiap pemecahan masalah harus melibatkan lebih dari sekedar penerapan suatu algoritma. Oleh karena itu, siswa yang memiliki kemampuan pemecahan masalah matematis yang baik akan menjadi pemecah masalah yang handal dalam berbagai situasi. Hal ini senada dengan Wahyudin (2008) yang menyatakan bahwa menjadi seorang pemecah masalah yang baik bisa membawa manfaat-manfaat besar dalam kehidupan sehari-hari dan dunia kerja.

Dalam proses pembelajaran matematika, siswa menggunakan pengetahuan yang dimiliki sehingga bisa membangun pemahaman matematis baru yang dapat digunakannya untuk mengetahui langkah yang harus dilakukan dalam menyelesaikan masalah yang dihadapi. Siswa menggunakan berbagai strategi pemecahan masalah untuk memecahkan permasalahan matematis yang dihadapi. Berdasarkan strategi-strategi yang dibentuk, siswa diharapkan mampu dan terampil dalam mengenali kapan dan bagaimana menggunakan strategi-strategi tersebut (Wahyudin, 2008). Lebih lanjut, siswa dapat mengembangkan kreativitasnya dalam menyelesaikan masalah matematis.

Berdasarkan uraian di atas, kemampuan pemecahan masalah matematis sangat diperlukan dalam pembelajaran matematika. Namun, kemampuan pemecahan masalah matematis masih belum mencapai hasil yang menggembirakan. Penelitian Aisyah (2012) yang meneliti tentang kemampuan pemecahan masalah dan representasi matematis siswa. Model pembelajaran yang dipilih secara signifikan dapat meningkatkan kedua kemampuan tersebut, namun 
peningkatan kemampuan pemecahan masalah matematis lebih kecil dibandingkan dengan kemampuan representasi matematis siswa. Hal ini menunjukkan bahwa kemampuan pemecahan masalah masih perlu ditingkatkan lagi. Penelitian lain yang dilakukan oleh Sadat (2013) terhadap kemampuan pemecahan masalah ditemukan aspek kemampuan pemecahan masalah yang masih rendah. Aspek tersebut adalah kelemahan siswa dalam mengkomunikasikan alasan-alasan dari pemakaian konsep yang digunakan pada langkah-langkah penyelesaian masalah, serta tidak menuliskan seluruh operasi algoritmis yang membuat siswa melewatkan langkah-langkah pengerjaan yang seharusnya.

Keberhasilan dan kegagalan suatu pembelajaran dipengaruhi oleh beberapa komponen baik guru, siswa, bahan ajar, proses belajar, tempat, dan waktu belajar. Dipandang dari segi komponen guru, keahlian guru dalam mengajar merupakan salah satu aspek yang dapat dikontrol untuk keberhasilan suatu pembelajaran. Salah satu caranya adalah dengan memilih model pembelajaran yang tepat untuk meningkatkan kemampuan siswa yang menjadi perhatian. Terdapat beberapa model pembelajaran yang dapat meningkatkan kemampuan pemecahan masalah dan self-confidence matematika, diantaranya adalah model pembelajaran sinektik dan pembelajaran berbasis masalah.

Model pembelajaran sinektik dan PBM memfasilitasi siswa untuk terlibat aktif dalam pembelajaran, siswa mengkonstruksi pengetahuan sendiri untuk memecahkan sebuah masalah. Perbedaan kedua model ini terletak pada elemen utama masing-masing model. Elemen utama model pembelajaran sinektik berada pada penggunaan analogi dan metafora, sedangkan elemen utama model PBM terletak pada penggunaan masalah kehidupan nyata sebagai sesuatu yang harus dipelajari siswa.

Elemen utama model pembelajaran sinektik yang merupakan penggunaan analogi dan metafora membantu siswa dalam mengembangkan gagasannya untuk menyelesaikan masalah. Dengan melakukan analogi-analogi, siswa akan merasa santai dan lebih menikmati tugasnya sehingga mereka bisa memecahkan masalah dengan baik dan memunculkan gagasan-gagasan yang menarik. Penggunaan masalah kehidupan nyata pada model pembelajaran berbasis masalah dipandang sebagai elemen utama yang dapat memberikan kesempatan kepada siswa untuk mempelajari pengalaman-pengalaman dan peran-peran orang dewasa, serta memungkinkan siswa meningkatkan sendiri kemampuan berpikir mereka. Hal ini dapat menumbuhkembangkan keterampilan menyelesaikan masalah yang lebih tinggi, memandirikan siswa dan meningkatkan kepercayaan diri siswa.

Tujuan penelitian ini adalah untuk mengetahui ada atau tidaknya perbedaan pencapaian dan peningkatan kemampuan pemecahan masalah antara siswa yang memperoleh pembelajaran sinektik dengan PBM. Selain itu, penelitian ini juga mempunyai tujuan lain yaitu untuk mengetahui ada atau tidaknya perbedaan pencapaian self-confidence matematika antara siswa yang memperoleh pembelajaran sinektik dengan PBM.

Berdasarkan uraian di atas, pembelajaran matematika sangat memerlukan kemampuan pemecahan masalah matematis dan self-confidence yang baik untuk mencapai tujuan pembelajaran. Sehingga peneliti merasa perlu untuk melakukan studi yang berkaitan dengan kemampuan pemecahan masalah matematis, selfconfidence siswa, penerapan model pembelajaran sinektik, dan PBM. Oleh karena itu pada penelitian ini akan dikaji "Kemampuan Pemecahan Masalah Matematis 
dan Self-Confidence Siswa SMK Melalui Pembelajaran Sinektik dan Pembelajaran Berbasis Masalah".

\section{KAJIAN TEORI}

\section{Kemampuan Pemecahan Masalah Matematis}

Mayer (Kirkley, 2003) mendefinisikan pemecahan masalah sebagai suatu proses yang mempunyai banyak langkah dalam menemukan hubungan antara pengalaman masa lalu dengan masalah yang dihadapi sekarang, kemudian bertindak untuk menyelesaikannya. Pemecahan masalah adalah proses yang digunakan oleh seseorang untuk merespon dan mengatasi berbagai kendala atau rintangan ketika suatu pemecahan atau metode pemecahan tidak tampak jelas secara langsung, pemecahan masalah harus melibatkan lebih dari sekedar penerapan suatu algoritma (Wahyudin, 2008). Oleh karena itu memecahkan masalah-masalah yang kompleks menuntut usaha yang sangat besar dan pemikiran yang kompleks pula. Dengan mempelajari pemecahan masalah di sekolah, siswa akan mendapatkan cara berpikir yang baik, ketekunan, rasa ingin tahu dan kepercayaan diri dalam menghadapi masalah yang mereka hadapi di luar sekolah.

Adapun indikator kemampuan pemecahan masalah matematis yang dikemukakan oleh Sumarmo (2012), yaitu sebagai berikut: (1) mengidentifikasi kecukupan data untuk pemecahan masalah, (2) membuat model matematik dari suatu situasi atau masalah sehari-hari dan menyelesaikannya, (3) memilih dan menerapkan strategi untuk menyelesaikan masalah matematika dan atau di luar matematika, (4) menjelaskan atau menginterpretasikan hasil sesuai permasalahan asal, serta memeriksa kebenaran hasil atau jawaban, dan (5) menerapkan matematika secara bermakna.

Indikator kemampuan pemecahan masalah matematis yang akan diukur dalam penelitian ini adalah sebagai berikut: (1) mengidentifikasi unsur-unsur yang diketahui, yang ditanyakan, dan kecukupan unsur yang diperlukan; (2) merumuskan masalah matematika atau menyusun model matematika; (3) menerapkan strategi untuk menyelesaikan berbagai masalah dalam atau diluar matematika; dan (4) menginterpretasikan hasil sesuai permasalahan asal serta memeriksa kebenaran hasil atau jawaban.

\section{Self-Confidence Matematika}

Self-confidence terdiri dari dua kata yaitu "self" yang berarti diri dan "confidence" yang berarti kepercayaan. Sehingga self-confidence dapat diartikan dengan kepercayaan diri. Menurut Cambridge Dictionary Online definisi dari selfconfidence adalah "feeling sure about yourself and your abilities" yang maknanya perasaan yakin terhadap diri sendiri dan kemampuan yang dimiliki dalam menghadapi segala sesuatu. Arti kepercayaan matematika menurut Schoenfeld (Hannula,M. S., Maijala, H., dan Pehkonen, 2004) adalah sebuah pemahaman dan perasaan individu yang membentuk cara tentang konsep individu dan menggunakannya dalam perilaku matematika. kepercayaan matematika dapat dibagi menjadi empat komponen: kepercayaan terhadap matematika, kepercayaan terhadap seorang pelajar matematika, kepercayaan terhadap mengajar matematika dan kepercayaan terhadap belajar matematika.

Percaya diri adalah langkah pertama untuk kemajuan, prestasi pembangunan, dan kesuksesan. Terbentuknya kepercayaan diri tidak terlepas dari 
perkembangan manusia. Kepercayaan diri individu merupakan salah satu aspek kepribadian manusia yang terbentuk dari interaksi dengan lingkungannya, terutama lingkungan yang mengandung interaksi sosial didalamnya, termasuk juga lingkungan keluarga. Suhardita (2011) menyatakan bahwa konsep dasar percaya diri adalah keyakinan untuk menjalani kehidupan, memilih pilihan dan membuat keputusan untuk diri sendiri. Kepercayaan diri diperoleh dari pengalaman hidup dan berhubungan dengan kemampuan melakukan sesuatu dengan baik. Percaya diri itu lahir dari kesadaran bahwa ketika seorang individu menentukan pilihannya maka ia akan melakukan sesuatu sesuai dengan pilihannya.

Self-confidence dalam penelitian ini adalah self-confidence matematis yaitu suatu keyakinan siswa pada diri sendiri tentang pengetahuan dan kemampuan yang dimiliki dalam mengerjakan soal atau masalah matematis yang dihadapi selama proses pembelajaran. Adapun indikator self-confidence yang dikemukakan oleh Sadat (2013), yaitu sebagai berikut: (1) percaya akan kompetensi/kemampuan diri dalam matematika, (2) menunjukkan kemandirian dalam mengambil keputusan serta tidak tergantung pada bantuan orang lain, (3) memiliki internal locus of control (memandang keberhasilan atau kegagalan tergantung pada usaha sendiri), (4) menunjukkan sikap positif dalam menghadapi masalah, (5) pandai bersosialisasi dan menyesuaikan diri dalam berkomunikasi pada berbagai situasi, dan (6) memiliki cara pandang yang objektif, rasional dan realistis.

Selanjutnya, disusun indikator self-confidence matematika dalam penelitian ini sebagai berikut: (1) percaya akan kemampuan diri dalam matematika dengan memiliki cara pandang yang objektif dan rasional; (2) menunjukkan kemandirian dalam mengambil keputusan dan tidak bergantung pada orang lain; (3) memiliki internal locus of control (memandang keberhasilan atau kegagalan tergantung pada usaha sendiri); (4) menunjukkan rasa optimis, bersikap tenang dan pantang menyerah dalam menyelesaikan masalah; dan (5) pandai bersosialisasi dan menyesuaikan diri dalam berkomunikasi pada berbagai situasi.

\section{Model Pembelajaran Sinektik}

Model pembelajaran sinektik merupakan model yang pertama kali dikembangkan oleh William J.J. Gordon (Seligmann, 2007). Pada awalnya model sinektik ini dikembangkan oleh Gordon dalam bidang industri. Tetapi setelah model ini berkembang pesat di bidang tersebut, Gordon telah menyesuaikan sinektik untuk digunakan dalam lingkungan sekolah dengan tujuan untuk menumbuhkan kreativitas sehingga diharapkan siswa mampu menghadapi permasalahannya. Langkah awal model pembelajaran ini adalah merumuskan masalah dan menulisnya di papan tulis agar dapat dilihat oleh guru dan siswa, selanjutnya kegiatan berlangsung di dalam kelas dengan guru sebagai pemimpin dan siswa sebagai pemimpin kelompok kecil (Munandar, 2012).

Gagasan utama dari pembelajaran sinektik ini adalah penggunaan analogi dan metafora untuk membantu mengembangkan berbagai sudut pandang. Ketika menghadapi suatu masalah dan masalah tersebut berhubungan dengan hal yang abstrak, kompleks dan sulit dijelaskan dengan panca indera maka seseorang akan cenderung melihat masalah itu dengan jernih, menjauh dari pemikiran logis dan mulai mencari alternatif (analogi) yang kiranya dapat digunakan untuk 
menyelesaikan masalah itu (Mutiawati, 2013). Dengan melakukan analogi-analogi siswa akan merasa santai dan akan lebih menikmati tugasnya sehingga mereka bisa memecahkan masalah dengan baik dan memunculkan gagasan-gagasan yang menarik (Munandar, 2012; Joyce, dkk., 2009).

Adapun langkah-langkah model pembelajaran sinektik yang digunakan dalam penelitian ini adalah sebagai berikut:

1. Tahap persiapan

Pada tahap ini, dilakukan aktivitas yang memusatkan perhatian siswa pada aktivitas pembelajaran. Guru memberikan gambaran tentang teknis pelaksanaan pembelajaran menggunakan model sinektik.

2. Latihan-latihan Peregangan (stretching exercises)

Latihan-latihan peregangan ini lebih ditekankan pada pengenalan analogi langsung (direct analogy), analogi personal (personal analogy), dan analogi konflik padat (compressed conflict analogy) kepada siswa melalui kegiatan mempelajari gambar yang diberikan oleh guru. Hal ini bertujuan sebagai usaha awal dalam proses membangkitkan pola pikir kreatif khususnya pada pemecahan masalah.

3. Tahap pengenalan konsep

Pada tahap ini, guru memberikan masalah-masalah tentang konsep-konsep geometri yang dapat membuka dimensi metaforis dalam diri siswa. Pada tahapan ini, prinsip teori dan pengetahuan yang dibangun didasarkan pada pengalaman estetis yang pernah dialami siswa.

4. Tahap berkreasi

Selanjutnya guru meminta siswa untuk berkreasi mencoba membuat analogi langsung dan personal serta membuat analogi konflik padat dari masalah yang disajikan dan analogi-analogi yang telah dihasilkan sebelumnya.

5. Presentasi karya

Tahapan ini merupakan tahapan terakhir dalam kegiatan pembelajaran sinektik. Pada tahap ini, siswa diminta untuk menulis dan menyajikan hasil diskusi mereka yang berhubungan dengan masalah yang telah disajikan serta kesimpulan akhir dari pembelajaran yang diperoleh. Hal ini merupakan tahapan penting dalam upaya mengembangkan kepercayaan diri, penghargaan pada usaha serta kemampuan membuat generalisasi dan mempertimbangkan hasil generalisasi.

\section{Model Pembelajaran Berbasis Masalah}

Model pembelajaran berbasis masalah (PBM) adalah suatu model pembelajaran yang menggunakan masalah kehidupan nyata untuk melatih dan meningkatkan kemampuan berpikir siswa dan membantu siswa mencapai keterampilan yang dimiliki (Hosnan, 2014). PBM juga dapat diartikan sebagai suatu pendekatan pembelajaran yang diawali dengan penyajian masalah yang dirancang dalam konteks yang relevan dengan materi yang akan dipelajari untuk mendorong pencapaian konsep dan mendorong kemandirian belajar (Sumarmo, 2013). Pemberian masalah yang berkaitan dengan kehidupan nyata dalam PBM membuat siswa lebih aktif dalam pembelajaran, dengan demikian siswa dapat mengetahui bahwa ada keterkaitan antara pembelajaran tesebut dengan kehidupan sehari-hari. Pemberian masalah di awal pembelajaran dapat mendorong siswa untuk meningkatkan kemampuan berpikir, kemampuan memecahkan masalah 
dalam kehidupan nyata serta mengembangkan kepercayaan siswa dalam menyelesaikan suatu masalah.

Adapun ciri-ciri dari PBM (Nur, 2011; Ibrahim, 2012; Arends, 2012): (1) mengorientasikan siswa kepada masalah autentik, (2) berfokus pada keterkaitan antar disiplin yaitu berpusat pada pembelajaran tertentu, (3) penyelidikan autentik yaitu menganalisis dan mendefinisikan masalah, (4) menghasilkan produk atau karya dan mempresentasikannya, dan (5) kolaborasi yaitu adanya kerjasama antar siswa baik secara berpasangan atau berkelompok.

Sintaks pembelajaran berbasis masalah (PBL) terdiri dari lima fase utama, yaitu: mengorientasikan siswa kepada masalah; mengorganisasikan atau mengatur siswa untuk belajar; membimbing penyelidikan mandiri atau kelompok; mengembangkan dan menyajikan hasil karya; menganalisis dan mengevaluasi proses pemecahan masalah (Nur, 2011).

Perbandingan langkah-langkah pembelajaran dengan menggunakan model pembelajaran sinektik dan PBM adalah sebagai berikut:

Tabel 1. Perbandingan Langkah-Langkah Pembelajaran Sinektik dan PBM

Sinektik PBM

a. Guru mendeskripsikan masalah kepada siswa untuk diselesaikan.

b. Guru mengusulkan analogi yang berhubungan dengan masalah yang ada.

a. Guru mengajukan fenomena atau cerita untuk memunculkan masalah dan memotivasi siswa untuk terlibat dalam penyelesaian masalah yang dipilihnya.

c. Siswa mengembangkan beberapa analogi fantasi dan menjadi bagian dari analogi yang dipilihnya.

d. Guru membimbing siswa dalam mengembangkan pemikiran analogi sebelumnya.

e. siswa mengidentifikasi dan menjelaskan ketidaksesuaian antara analogi yang dipaparkan dengan materi yang sedang dipelajari.

f. Guru membimbing siswa dalam mengeksplorasi masalah berdasarkan analogi yang dipaparkan.

g. siswa mengeksplorasi kembali topik asli, apakah sudah cocok atau belum dengan analogi yang telah dipaparkan.

b. Siswa memilih masalah berdasarkan fenomena atau cerita yang ada.

c. Guru membantu siswa mendefinisikan dan mengorganisasikan tugas belajar yang berhubungan dengan masalah dan membentuk kelompok belajar.

d. Siswa membentuk kelompok belajar dan memperhatikan penjelasan dari guru.

e. Guru mendorong siswa untuk mengumpulkan informasi yang sesuai.

f. Siswa mengumpulkan informasi yang sesuai dan melakukan eksperimen untuk mendapatkan penyelesaian masalah.

h. Guru mengarahkan siswa kembali kepada masalah semula dengan menggunakan analogi terakhir.

i. Siswa menggunakan analogi terakhir untuk mengarah kepada penyelesaian masalah semula.

j. Guru membimbing siswa dalam g. Guru membantu siswa dalam 
menuliskan hasil diskusi serta merencanakan hasil diskusi dari kesimpulan akhirnya. tugas.

k. Siswa menulis dan mempresentasikan hasil diskusi serta menyajikan kesimpulan akhirnya.

1. Guru bersama siswa melakukan refleksi atau evaluasi terhadap berlangsungnya pemikiran analogi dalam proses pemecahan masalah.

h. Siswa merencanakan dan menyiapkan hasil diskusi yang sesuai dengan tugas yang diberikan.

i. Guru membantu siswa untuk melakukan refleksi atau evaluasi terhadap penyelidikan siswa dan proses yang digunakan.

\section{METODE PENELITIAN}

Penelitian ini merupakan penelitian kuasi eksperimen sebab dalam penelitian ini peneliti tidak dapat melakukan pengambilan sampel secara acak. Hal ini dikarenakan pengambilan sampel secara acak dapat megganggu jadwal pelajaran yang telah ditetapkan oleh sekolah. Penelitian ini dilakukan untuk mengetahui hubungan sebab akibat dari dua jenis pembelajaran terhadap kemampuan pemecahan masalah matematis dan self-confidence matematika.

Pada penelitian ini dipilih dua sampel yang mendapatkan perlakuan yang berbeda, yaitu kelas eksperimen 1 dan kelas eksperimen 2. Sebelum pembelajaran, kedua kelas diberikan pre-response yaitu pretes kemampuan pemecahan masalah matematis untuk mengetahui hasil dari kedua kelas sebelum diberikan perlakuan. Kelas eksperimen 1 diberikan perlakuan model pembelajaran sinektik dan kelas eksperimen 2 diberikan perlakuan model PBM. Setelah pembelajaran, kedua kelas diberikan post-response yaitu postes kemampuan pemecahan masalah matematis serta skala self-confidence matematika untuk mengetahui keberpengaruhan model pembelajaran yang telah dilaksanakan terhadap kemampuan pemecahan masalah matematis dan self-confidence matematika. Skala self-confidence matematika hanya diberikan setelah pembelajaran karena analisis yang dilakukan adalah pencapaian self-confidence matematika.

Instrumen yang digunakan dalam penelitian ini terdiri dari instrumen tes dan non-tes. Instrumen tes meliputi tes kemampuan pemecahan masalah matematis. Sedangkan instrumen non-tes berupa skala self-confidence matematika yang digunakan untuk mengetahui tingkat self-confidence siswa.

Data yang diperoleh dari penelitian ini adalah berupa data kuantitatif yaitu data hasil tes kemampuan pemecahan masalah matematis serta skala selfconfidence matematika. Selanjutnya data-data tersebut akan dianalisis dengan menggunakan bantuan Software Microsoft Excel 2007 dan SPSS 20.0 for Windows. Analisis data yang dilakukan meliputi menghitung skor peningkatan dengan rumus gain ternormalisasi, uji normalitas dan homogenitas, serta melakukan pengujian perbedaan rata-rata.

\section{HASIL DAN PEMBAHASAN}

Kemampuan pemecahan masalah matematis merupakan kemampuan menyelesaikan suatu masalah matematika dengan menerapkan gagasan-gagasan dasar dan langkah-langkah dalam proses pemecahannya. Empat tahap proses pemecahan masalah menurut Polya (1973), yaitu memahami masalah, 
merencanakan penyelesaian masalah, melaksanakan rencana penyelesaian masalah, dan pemeriksaan kembali. Adapun indikator kemampuan pemecahan masalah matematis yang digunakan dalam penelitian ini adalah sebagai berikut: (1) mengidentifikasi unsur-unsur yang diketahui, yang ditanyakan, dan kecukupan unsur yang diperlukan; (2) merumuskan masalah matematika atau menyusun model matematika; (3) menerapkan strategi untuk menyelesaikan berbagai masalah dalam atau diluar matematika; dan (4) menginterpretasikan hasil sesuai permasalahan asal serta memeriksa kebenaran hasil atau jawaban.

Tabel 2. Rerata Pretes Kemampuan Pemecahan Masalah

\begin{tabular}{cc}
\hline Kelas & Rerata Postes \\
\hline Sinektik & 2,12 \\
\hline PBM & 1,97 \\
\hline
\end{tabular}

Analisis data pretes kemampuan pemecahan masalah matematis kedua kelas menunjukkan bahwa tidak ada perbedaan yang signifikan. Rerata kemampuan pemecahan masalah matematis sebelum dilakukan pembelajaran pada kelas sinektik dan kelas PBM adalah sebesar 2,12 dan 1,97. Selisih rerata dari kedua kelas adalah 0,15 dengan kelas sinektik lebih tinggi daripada kelas PBM. Untuk mengetahui apakah perbedaan tersebut signifikan atau tidak, dilakukan uji Mann-Whitney dan nilai signifikansi yang diperoleh adalah 0,575. Nilai tersebut lebih besar dari taraf signifikansi 0,05, sehingga dapat disimpulkan bahwa H0 diterima atau kelas sinektik dan kelas PBM tidak berbeda secara signifikan. Hal ini sesuai dengan asumsi peneliti bahwa kemampuan awal siswa di kedua kelas sebelum diberikan perlakuan adalah sama.

Tabel 3. Rerata Postes Kemampuan Pemecahan Masalah

\begin{tabular}{cc}
\hline Kelas & Rerata Postes \\
\hline Sinektik & 8,67 \\
\hline PBM & 7,58 \\
\hline
\end{tabular}

Setelah pembelajaran, pencapaian kemampuan pemecahan masalah matematis siswa kelas sinektik dan kelas PBM menunjukkan hasil yang tidak berbeda secara signifikan pada uji statistik. Pencapaian dapat dilihat dari hasil postes kemampuan pemecahan masalah matematis siswa. Rerata postes kemampuan pemecahan masalah matematis siswa kelas sinektik sebesar 8,67 atau $54,19 \%$, sedangkan rerata postes kelas PBM sebesar 7,58 atau 47,38\%. Nilai rerata postes kedua kelas tersebut tidak jauh berbeda, dengan selisih rerata 1,09 atau $6,81 \%$. Sehingga dapat disimpulkan bahwa pencapaian kemampuan pemecahan masalah matematis siswa kelas sinektik tidak berbeda dengan siswa kelas PBM.

Setelah pemberian perlakuan pada kedua kelas, terlihat adanya peningkatan di kedua kelas. Untuk mengetahui peningkatan kemampuan pemecahan masalah matematis kedua kelas, maka dilakukan analisis terhadap data skor N-gain yang diperoleh dari hasil bagi antara selisih skor postes dan skor pretes dengan selisih skor maksimal dan skor pretes. Berdasarkan uji MannWhitney $\mathrm{N}$-gain kemampuan pemecahan masalah matematis, diperoleh nilai signifikansi 0,170 artinya Ho diterima atau tidak terdapat perbedaan yang signifikan antara siswa yang memperoleh model pembelajaran sinektik dengan 
siswa yang memperoleh model PBM. Hal ini terjadi dimungkinkan karena model pembelajaran sinektik dan model PBM sama-sama menitikberatkan siswa pada proses pemecahan masalah.

Pembelajaran dengan model pembelajaran sinektik dan PBM merupakan dua model pembelajaran yang menitikberatkan siswa pada proses pemecahan masalah. Kedua model tersebut dimulai dengan penyajian masalah yang harus diselesaikan oleh siswa. Masalah-masalah yang diberikan berkaitan dengan kehidupan nyata sehingga dapat mendorong siswa untuk memecahkan masalah tersebut dan meningkatkan kepercayaan diri siswa dalam menyelesaikan suatu masalah yang berkaitan dengan kehidupan sehari-hari.

Tahap latihan-latihan Peregangan (stretching exercises) dan tahap pengenalan konsep pada model pembelajaran sinektik memuat suatu hal yang berhubungan dengan proses pemecahan masalah, yaitu membangkitkan pola pikir siswa dalam memecahkan masalah dan membangun prinsip, teori serta pengetahuan berdasarkan pada pengalaman estetis yang pernah dialami siswa. Sehingga siswa dapat mengembangkan berbagai cara untuk menyelesaikan masalah berdasarkan analogi-analogi yang dibuat pada tahapan latihan-latihan Peregangan (stretching exercises). Hal inilah yang membuat model pembelajaran sinektik dapat meningkatkan kemampuan pemecahan masalah matematis siswa. Sedangkan tahapan mengorientasikan siswa kepada masalah dan tahapan penyelidikan mandiri atau kelompok pada model PBM sangat mempengaruhi pola pikir siswa dalam menyelesaikan suatu masalah. Pada tahapan ini, siswa membangun sendiri konsep yang dipelajari berdasarkan pengetahuan yang dimiliki dan hasil dari penyelidikan masalah yang dilakukan siswa. Siswa mengumpulkan berbagai informasi untuk menyelesaikan masalah yang disajikan dari berbagai sumber, sehingga membuat siswa memiliki pandangan yang luas mengenai pemecahan masalah. Dengan demikian, siswa akan terbiasa menyelesaikan masalah yang dihadapinya. Oleh karena itu, model PBM dapat meningkatkan kemampuan pemecahan masalah siswa.

Berdasarkan hasil perhitungan rerata skor kemampuan pemecahan masalah matematis kelas pembelajaran sinektik yang awalnya 2,12 meningkat menjadi 8,67 setelah pembelajaran dengan rerata $\mathrm{N}$-gain adalah 0,47 . Sedangkan hasil perhitungan rerata skor kemampuan pemecahan masalah matematis kelas PBM adalah 1,97 sebelum pembelajaran dan 7,58 setelah pembelajaran dengan rerata $\mathrm{N}$-gain adalah 0,40 . Hal ini berarti bahwa model pembelajaran sinektik dan PBM sama-sama memberikan pengaruh positif terhadap kemampuan pemecahan masalah matematis siswa di kedua kelas dengan rerata $\mathrm{N}$-gain yang hampir sama, yaitu tergolong kategori cukup. Sehingga tidak terdapat perbedaan yang signifikan antara peningkatan kemampuan pemecahan masalah matematis siswa pada kelas pembelajaran sinektik dengan siswa pada kelas PBM.

Meskipun terjadi peningkatan kemampuan pemecahan masalah matematis pada kelas sinektik dan kelas PBM, namun peningkatan kemampuan pemecahan masalah matematis di kedua kelas tersebut masih tergolong rendah. Berdasarkan analisis kesulitan siswa dalam tes kemampuan pemecahan masalah matematis, baik siswa kelas sinektik maupun kelas PBM masih mengalami kesulitan yang sama. Pada umumnya siswa kelas sinektik maupun kelas PBM tidak menuliskan proses pemecahan masalah secara algoritmis. Banyak siswa yang mempunyai jawaban akhir yang benar namun langkah-langkah penyelesaiannya tidak 
dituliskan dengan lengkap. Selain itu, banyak siswa yang tidak menuliskan interpretasi jawaban sesuai dengan permasalahannya. Sehingga kemampuan pemecahan masalah matematis siswa pada sekolah tempat dilakukannya penelitian masih perlu perbaikan.

\section{SIMPULAN DAN SARAN}

Berdasarkan hasil penelitian ini disimpulkan bahwa: 1) pencapaian dan peningkatan kemampuan pemecahan masalah matematis siswa kelas sinektik tidak berbeda dengan siswa kelas PBM. Hal ini terjadi karena model pembelajaran sinektik dan PBM dapat meningkatkan kemampuan pemecahan masalah matematis; 2) Pencapaian self-confidence matematika siswa kelas sinektik tidak berbeda dengan siswa kelas PBM. Hal ini dikarenakan penelitian ini dilakukan dengan waktu yang relatif tidak lama, karena sikap atau afektif seseorang tidak dapat meningkat dalam waktu yang relatif cepat.

Implikasi dari penerapan model pembelajaran sinektik dan PBM di SMK yaitu meningkatnya kemampuan pemecahan masalah matematis siswa, khususnya dalam menyelesaikan konsep geometri. Selain itu, penerapan kedua model pembelajaran tersebut mampu menumbuhkembangkan self-confidence siswa dalam pembelajaran matematika di kelas.

Berdasarkan kesimpulan dan implikasi dari hasil penelitian di atas, maka direkomendasaikan kepada guru matematika di sekolah untuk dapat menerapkan model pembelajaran sinektik dan PBM dalam pembelajaran matematika di kelas, dengan tujuan untuk meningkatkan kemampuan pemecahan masalah matematis dan mengembangkan self-confidence siswa. Pembelajaran dengan menggunakan model sinektik dan PBM mengharuskan guru untuk dapat mengatur waktu pembelajaran dengan baik. Oleh karena itu, diharapkan kepada guru matematika untuk dapat merencakan pembelajaran secara efektif dan efisien, sehingga tujuan pembelajaran dapat tercapai secara optimal.

\section{DAFTAR RUJUKAN}

Aisyah, S. (2012). Meningkatkan Kemampuan Presentasi dan Pemecahan Masalah Matematis Melalui Mathematical Modelling dalam Model Problem Based Learning. (Tesis). Sekolah Pascasarjana Universitas Pendidikan Indonesia, Bandung, tidak dipublikasi.

Arends, R. I. (2012). Learning to Teach, $9^{\text {th }}$ edition. New York: The McGraw-Hill Companies, Inc.

Hannula, M. S., Maijala, H., \& Pehkonen, E. (2004). Development of Understanding and Self-Confidence In Mathematics; Grade 5-8. Proceedings of the 28th Conference of the International Group forthe Psychology of Mathematics Education, 2004. Finland, Department of Teacher Education, University of Turky, Vol. 3 pp. 17-24.

Hosnan, M. (2014). Pendekatan Saintifik dan Kontekstual dalam Pembelajaran Abad 21. Bogor: Ghalia Indonesia.

Ibrahim, M. (2012). Pembelajaran Berdasarkan Masalah. Surabaya: Unesa University Press.

Joyce, B., Weil, M., \& Calhoun, E. (2009). Models of Teaching; Model-Model Pengajaran. Yogyakarta: Pustaka Belajar. 
Kirkley, J. (2003). Principles For Teaching Problem Solving. Indiana University: Copyright Plato Learning.

Munandar, U. (2012). Pengembangan Kreativitas Anak Berbakat. Jakarta: Rineka Cipta.

Mutiawati. (2013). Pengaruh Pembelajaran Sinektik Terhadap Peningkatan Kemampuan Berpikir Kritis dan Kreatif Matematis Mahasiswa PGSD. (Tesis). Sekolah Pascasarjana Universitas Pendidikan Indonesia, Bandung, tidak dipublikasi.

Nur, M. (2011). Model Pembelajaran Berdasarkan Masalah. Surabaya: Pusat Sains dan Matematika Sekolah Unesa.

Polya, G. (1973). How To Solve It. Stanford University

Sadat, A. (2013). Implementasi Model Pembelajaran Missouri Mathematics Project dalam Upaya Meningkatkan Kemampuan Pemecahan Masalah Matematis dan Self-confidence Siswa Madrasah Tsanawiyah. (Tesis). Sekolah Pascasarjana Universitas Pendidikan Indonesia, Bandung, tidak dipublikasi.

Seligmann, E. R. (2007). Reaching Students Through Synectics : A Creative Solution. EDF 500-Educational Foundations and Curriculum Studies. University of Northern Colorado.

Suhardita, K. (2011). Efektivitas Penggunaan Teknik Permainan dalam Bimbingan Kelompok Untuk Meningkatkan Percaya Diri Siswa. Edisi Khusus No.1, Agustus 2011. ISSN 1412 565X.

Sumarmo, U. (2012). Proses Berpikir Matematik: Apa dan Mengapa Dikembangkan. Dalam Sumarmo, U. (Editor). Berpikir dan Disposisi Matematika Serta Pembelajarannya. Bandung: FPMIPA UPI, tahun 2013 hlm. 435-493.

Wahyudin. (2008). Pembelajaran dan Model-Model Pembelajaran. Diktat Kuliah. Bandung. 